$4(31) / 2015$

\author{
Barbara Bilewicz-Kuźnia \\ Uniwersytet Marii Curie-Skłodowskiej \\ barbara.bilewicz@poczta.umcs.lublin.pl
}

Malgorzata Centner-Guz

Uniwersytet Marii Curie-Skłodowskiej

malgorzata.centner-guz@poczta.umcs.lublin.pl

\title{
Natura, architektura i zabawa jako źródła przeżyć estetycznych i odkryć geometrycznych dzieci - badania w działaniu
}

\begin{abstract}
Summary
Nature, architecture and play as the sources of children's aesthetic experiences and geometrical discoveries - action research

Every child has an innate sense of rhythm, beauty and harmony, enjoys observing nature and architecture, plays with the gifts of nature and decorates. As a matter of fact, in the course of such activities the child not only experiences pleasure, but also discovers new phenomena, refines visual perception and aesthetic sensitivity, constructs mathematical concepts, enters the world of geometry. The relationship between nature and art, play and culture, as well as the educational significance of observation and activity have been stressed by a number of researchers into child development, including Maria Montessori. She claimed that for a child, learning is a natural process, occurring spontaneously not thanks to passive listening, but thanks to active contact with the environment. The didactic materials she devised are characterized by purposefulness, isolated difficulty, stimulation of the child, visual beauty and order. The source of their beauty lies, above all, in their simplicity and transparency. M. Montessori's and F. Froebel's educational materials were the inspiration for devising original teaching aids, Esy floresy blocks. The current paper presents the methods of using them for playing, observing nature and architecture, that were validated in action research. The aim of the methodological solutions described here is to sensitize children to discovering beauty and geometrical dependencies in their surroundings, as well as to develop their spatial thinking.
\end{abstract}

Słowa kluczowe: filozofia edukacyjna Fröebla, poglądy M. Montessori, dziecko, wrażliwość estetyczna, odkrycia geometryczne, materiał dydaktyczny

Keywords: Fröebel's approach, M. Montessori's views, the child, aesthetic sensitivity, geometrical discovers, didactic materials 


\section{Wprowadzenie}

Od najdawniejszych czasów człowiek tworzył przedmioty i budowle, które nie tylko służyły mu w codziennej egzystencji, ale także były wyrazem jego potrzeby twórczej ekspresji i kontaktu z pięknem. Zachwycony estetyką otaczającego świata ozdabiał i dekorował motywami roślinnymi przedmioty życia codziennego, ściany, budynki, tkaniny. Dekorowanie umożliwiało mu bezpośrednie uzewnętrznienie wrodzonego poczucia rytmu i harmonii, mobilizowało do wysiłku umysłowego.

Twórcza aktywność związana z badaniem kształtów i przestrzeni oraz ozdabianiem była w przeszłości i jest nadal przedmiotem zainteresowań badaczy rozwoju dziecka. Zagadnieniami tymi zajmowali się Johann Heinrich Pestalozzi, Jean Jacques Rousseau, Friedrich Fröebel, Maria Montessori. Współcześnie uznaje się ją za warunek rozwoju kreatywności, ale także stymulator rozwoju myślenia matematycznego i przestrzennego (por. Popek 1998; Limont 1994, 1999; Popek 1982, 1984, 2003; Uszyńska-Jarmoc 2003; Nęcka 2001; Giza 2006; Swoboda 2006; Swoboda E., J. Gunčaga 2009; Davis 2015).

Istotą zaplanowanych, zrealizowanych i opisanych w niniejszym opracowaniu badań w działaniu było wprowadzenie do praktyki pedagogicznej propozycji metodycznych, z wykorzystaniem nietypowych środków dydaktycznych - klocków Esy floresy i towarzyszących im materiałów dodatkowych. Jak określa Dariusz Kubinowski (2010: 185) badanie w działaniu implikuje rozwój koncepcji siebie i kompetencji uczestników, dlatego interesujące było dla nas to, czy i w jakim zakresie możliwe będzie zorganizowanie sytuacji edukacyjnych we wspólnym działaniu badaczy, nauczyciela i dzieci, czy i w jakim zakresie proponowana dzieciom aktywność z wykorzystaniem nowego materiału dydaktycznego będzie sprzyjała rozwojowi intuicji geometrycznej i kreatywności oraz jak uczestnicy badań ocenią proponowane im zajęcia i materiały dydaktyczne.

\section{Doświadczanie otoczenia jako droga budowania wiedzy fizycznej i logiczno-matematycznej w poglądach pedagogicznych Froebla i Montessori}

W poglądach pedagogicznych przedstawicieli nurtu Nowego Wychowania, między innymi F.W. Fröebla (1792-1852) i M. Montessori (1870-1952) zauważa się odniesienia do natury i otoczenia kulturowego jako źródeł istotnych wrażeń i spostrzeżeń, będących podstawą kształtowania się wiedzy fizycznej i logiczno-matematycznej.

F.W. Fröebel, należący do kręgu idealistów, bliski poglądom F.W. Schellinga, G.W. Hegla, J.G. Fichtego i I. Kanta, swój pedagogiczno-filozoficzny pogląd na świat oparł na wiecznym prawie dotyczącym świadomości siebie i jedności z Bogiem. Jako wykształcony przyrodnik szukał inspiracji pedagogicznych w obserwacji otoczenia. Dowodził, że wszystko ma w nim swoje źródła, a człowiek żyje w systemie wzajemnie powiązanych zależności ekologicznych. W swoim największym dziele Wychowanie czlowieka (1826) pisał, że więzi dziecka z całym światem muszą być także odzwierciedlane w procesie edukacyjno-wychowawczym. Porządek w organizowaniu dzieciom uczenia się wyraża się, 
według jego koncepcji, w przekonaniu, że świat poznawany jest całościowo, a nie fragmentarycznie. Nowe zagadnienia powinny być widziane w szerszym kontekście, w relacjach ze światem i jego prawami w całości. Każdy aspekt nowego doświadczenia powinien odnosić się do innego, wiązać się z kolejnym, pozwalać zgłębiać rozumienie świata poprzez szukanie relacji między obiektami, rzeczami, zjawiskami, by widzieć zagadnienie nie wąsko i nie w izolacji, ale szeroko i wieloaspektowo. Holistyczne podejście F.W. Fröebla podkreśla jedność, która istnieje w przyrodzie i jednocześnie zasadę, że „wszystko co następuje powinno wynikać z tego, co poprzedza" (Wąsik 1932: 231).

Natura, zdaniem F.W. Fröebla, jest punktem wyjścia do budowania szerokiej wiedzy o świecie, pozwala też lepiej zrozumieć abstrakcyjny i skomplikowany świat idei, w tym pojęć matematycznych. Dlatego dzieciom należy dawać do zabawy materiał naturalny: piasek, glinę, muszle, kamyki, ale także materiały plastyczne i konstrukcyjne, szczególnie różnego rodzaju papier i klocki, dzięki którym będą one mogły odtwarzać obserwowane w naturze formy życiowe (zwane kształtami naturalnymi i kształtami piękna), zbliżając się stopniowo do ścisłego ich pojmowania. Natalia Cicimirska pisała o tym następująco: „W celu przyswajania różnorodnych pojęć, a przede wszystkim kształcenia zręczności w palcach i spostrzegawczości, posługiwał się Fröebel całym szeregiem zajęć. Dla uzmysłowienia pojęcia 1) punktu służyły: wykłuwanie, układanki muszelkami lub kamykami; 2) linii: układanie patyczków, nitek, rysowanie, wyszywanie, robienie łańcuszków; 3) płaszczyzny: wyplatanie, składanie wycinanie; 4) bryły: budowanie z klocków i modelowanie. Przy tych zajęciach dziecko buduje i niszczy, maluje lub tworzy. Rozmaitość ich jest dość wielka. Twórca tej metody nie krępuje pomysłowości swych następców, zostawia wiele swobody, żądając jedynie, ażeby nowość opierała się na psychologicznych zasadach, aby była zgodna z naturą dziecięcą i rozwijała jego umysł bez znużenia" (Cicimirska 1928:3-4).

F.W. Fröebel uznając za konieczne ,dostarczenie wychowankowi wiadomości o przyrodzie i jej formach, wyrażających się w obrazach geometrycznych i liczbie; nauczanie słowa i mowy oraz rozwinięcie poczucia piękna i wrodzonego dążenia do Boga" (Żukiewiczowa 1935: 105), stworzył materiał pedagogiczny, który miałby te zadania ułatwiać. Pomoce, jakimi były wełniane piłeczki, drewniane przestrzenne klocki, wielokształtne płaskie płytki, patyczki i pierścienie zostały nazwane darami. Dzięki obserwacji natury i aktywności własnej z darami przyrody i darami-materiałami dydaktycznymi, dzieci w trakcie zabaw swobodnych i gier mogły doskonalić sprawności percepcyjne, językowe, matematyczne i twórcze. N. Cicimirska określała propozycje F.W. Fröebla jako twórcze i inspirujące dla innych pedagogów. Pisała na ten temat: „genialna metoda Froebla została w XX wieku przystosowana do wymagań współczesnej pedagogiki i psychologii eksperymentalnej i niejako odnowiona w twórczych pomysłach włoskiej uczonej dr Marii Montessori, autorki Domów dziecięcych" (Cicimirska 1928: 19). W konsekwencji pojawił się jeszcze bardziej rozbudowany system edukacyjny podkreślający rolę obserwacji natury i sztuki oraz podejmowania samodzielnych działań sprzyjających gromadzeniu wrażeń sensorycznych i estetycznych, umożliwiających dokonywanie odkryć geometrycznych. 
Dla M. Montessori impulsem do opracowania nowego systemu pedagogicznego była coraz bardziej powszechna w jej czasach ostra krytyka herbartowskiej „,szkoły tradycyjnej”. Włoszka, która doświadczyła surowej dyscypliny systemu tradycyjnego, jego formalizmu dydaktycznego i przedmiotowego traktowania ucznia w oddziaływaniach dydaktycznych i wychowawczych, opracowaną przez siebie metodę oparła na pedagogicznych zasadach indywidualności, samodzielności i wolności. Nie bez znaczenia jest fakt, że M. Montessori zdobywała wykształcenie w XIX wieku, a jej koncepcja pedagogiczna kształtowała się na przełomie drugiego i trzeciego tysiąclecia oraz w pierwszych dziesięcioleciach wieku XX. Rozwijające się w tym okresie teorie psychologiczne określały istotę nauczania i funkcje wychowania. M. Montessori jako lekarz i pedagog skłaniała się ku teorii romantycznego naturalizmu, który odkrywał dziecko, jego potrzeby, zainteresowania, ale jednocześnie podkreślał dominującą rolę czynnika biologicznego w rozwoju jednostki. Rolą wychowania i nauczania w jej koncepcji było doskonalenie i utrwalanie osiągnięć rozwojowych dziecka (Brzezińska 2007: 126). Teoria pedagogiczna M. Montessori była i jest wielokrotnie krytykowana za jej natywistyczne przesłanki. Jednak fundamentalne założenie, dotyczące znaczenia aktywności w procesie uczenia się i nauczania, pozwala dostrzegać w formułowanych przez nią podstawach teoretycznych idee konstruktywistyczne (Bałachowicz 2004: 59). Ciągle aktualna jest także wartość zasad pedagogicznych, którym hołdowała M. Montessori, jej wizja dziecka i roli nauczyciela w osiąganiu niezależności fizycznej i duchowej wychowanka oraz ,pomocy jako nośnika wspólnej aktywności, w jaką dziecko i nauczyciel angażują się, gdy ten drugi pośredniczy w wykonywaniu złożonego zadania na rzecz tego pierwszego" (Cylkowska-Nowak 2009: 88).

Jądrem systemu pedagogicznego M. Montessori jest tak zwane ,przygotowane otoczenie", stanowiące uporządkowany teren doświadczeń edukacyjnych dzieci. Jego strukturę regulują charakterystyczne w kolejnych fazach rozwoju „okresy szczególnej wrażliwości" (zainteresowania wybranymi elementami otoczenia i podatności na opanowanie określonych umiejętności/sprawności) oraz specyfika funkcjonowania intelektualnego (opartego na manipulacjach materiałem konkretnym, potem wyobrażeniowym, w końcu abstrakcyjnym).

Zdaniem M. Montessori, dziecko do 6. roku życia gromadzi wrażenia w kontakcie ze światem zewnętrznym. Między 3 a 6 rokiem życia, w odróżnieniu od poprzedniej fazy rozwoju (kiedy to ma miejsce nieświadoma ,absorpcja”), czyni to w sposób świadomy. Instrumentem poznawania świata $\mathrm{w}$ tym czasie stają się zmysły dziecka, stąd na etapie wychowania przedszkolnego M. Montessori szczególną wagę przykładała do ich kształcenia (Montessori 2014: 96). Opracowany przez nią materiał sensoryczny ma do dziś znaczenie w rozwoju wszystkich sfer osobowości dziecka (zob. Miksza 1997: 54; Guz 2006: 41-51). Estetyczny wygląd materiałów rozwojowych, zachęcający dziecko do sięgnięcia po nie, wyzwala aktywność ruchową (organizacja miejsca pracy przez rozłożenia dywanika, przyniesienie pomocy), manipulacyjną (badanie poszczególnych - zazwyczaj dziesięciu - elementów, porządkowanie, wykonywanie zaprezentowanych przez nauczyciela ćwiczeń, działania twórcze - eksperymentowanie, tworzenie własnych wzorów, układów, 
kompozycji) oraz intelektualną. Montessori wyjaśniała wartość materiałów sensorycznych określając je „zmaterializowanymi abstrakcjami” (za: Fischer 2005: 12). Sądziła, że takie czynności, jak rozpoznawanie elementów identycznych i porównywanie różniących się, tworzenie serii, klasyfikowanie przedmiotów (elementów kompletu materiału rozwojowego) z uwzględnieniem określonych cech fizykalnych i ich werbalizowanie, prowadzą do kształtowania pojęć ogólnych oraz rozwijają myślenie matematyczne. W istocie, ćwiczenia podejmowane przez dzieci podczas pracy z materiałami do rozwijania zmysłów stanowią okazję do kształcenia wielu tzw. piagetowskich pojęć i operacji poznawczych (Guz 2006: 49). Co ważne, umożliwiają także wzrokowe i dotykowe doświadczanie brył geometrycznych podczas ćwiczeń związanych z kształtowaniem pojęć wielkościowych (np. sześcianów „różowej wieży” służącej kształtowaniu pojęć duży/większy/największy - mały/mniejszy/najmniejszy, prostopadłościanów „brązowych schodków” służących kształtowaniu pojęć gruby/grubszy/najgrubszy - cienki/cieńszy/najcieńszy, prostopadłościanów „czerwonych beleczek” służących kształtowaniu pojęć dtugi/dluższy/najdluższy - krótki/krótszy/najkrótszy, walców „bloków cylindrycznych” i „kolorowych walców” służących kształtowaniu m.in. pojęć wysoki - niski, szeroki - wąski). Należy dodać, iż bezpośrednie poznawanie figur płaskich i przestrzennych ma także miejsce w metodyce opracowanej przez M. Montessori w ramach kształcenia sensorycznego, za sprawą takich materiałów dydaktycznych, jak „,szafka geometryczna” (zawierająca koła, prostokąty, trójkąty, równoległoboki, owal oraz kształty nieposiadające nazw matematycznych), „trójkąty konstrukcyjne” (umożliwiające konstruowanie rozmaitych figur geometrycznych), „bryły w koszyku” (kula, prostopadłościany, ostrosłupy, elipsoidy, stożek, walec). Obok zasadniczego celu pracy z wymienionymi materiałami (doskonalenie postrzegania zmysłowego kształtów i kształtowanie określonych pojęć), autorka podkreślała także inny ich walor słowami: „Znajomość przedstawionych dziecku kształtów [...] będzie dla niego swego rodzaju magicznym kluczem do interpretowania prawie całego zewnętrznego otoczenia i da mu krzepiące wrażenie znajomości sekretów świata" (Montessori 2014: 148). Zalecenia metodyczne M. Montessori dotyczące pracy dziecka $z$ figurami płaskimi i przestrzennymi sugerują, że problemy teoretyczne (nazywanie i określanie cech) zawsze powinny być poprzedzone samodzielną pracą badawczą (manipulowanie, konstruowanie, badanie pojemności). Na kolejnych poziomach kształcenia (obejmujących trzyletnie cykle), treści geometryczne realizowane są w ramach edukacji matematycznej, z wykorzystaniem właściwych materiałów dydaktycznych, stanowiących elementy „przygotowanego otoczenia".

Montessoriańska idea „przygotowanego otoczenia” oparta jest na przekonaniu twórczyni metody, że środowisko kształcenia dzieci ma umożliwiać nawiązywanie relacji z przyrodą, zdobyczami cywilizacji i kultury w sposób aktywny, w efekcie czego powinny one zdobywać krok po kroku niezależność fizyczną, intelektualną i moralną. Łącznikiem pomiędzy między tymi elementami środowiska życia dziecka powinien być nauczyciel (Surma 2008: 59). Dlatego M. Montessori doceniała znaczenie obserwacji otoczenia (natury i wytworów kultury), zwłaszcza przez dzieci po 5. roku życia. Sformułowała spo- 
strzeżenia dotyczące charakteru dziecięcych obserwacji, podkreślając, iż są one: nie pasywne, ale aktywne; nie sporadyczne, ale ciągłe; nie płytkie i bezrefleksyjne, ale dokładne i pogłębione; nie zdystansowane i wyrachowane, ale czynione $\mathrm{z}$ głębokim zainteresowaniem i pasją (za: Berg 2006: 57). Troszczyła się także o to, by jej wychowankowie mieli sposobność bezpośredniego kontaktu z sztuką malarską i architekturą. Gromadziła w związku z tym w sali wydawnictwa albumowe, zawierające reprodukcje najbardziej wartościowych artystów.

Jak zaznaczają niemieccy badacze działalności pedagogicznej M. Montessori, lekarka i twórczyni autorskiego systemu wychowania dzieci, niezbyt rozlegle udokumentowała swoje poglądy i rozwiązania metodyczne dotyczące sztuk wizualnych (malarstwa, architektury) (Berg 2006: 43, Gebhardt-Seele 2006: 155). Jednakże w wybranych pracach (Montessori 1976 i 2010) określa znaczenie działalności plastycznej dzieci i jej uwarunkowania. Działalność artystyczna dziecka - w poglądach Włoszki - stanowiła przede wszystkim wyraz jego twórczego potencjału i potrzeby ekspresji wewnętrznych przeżyć (duchowości dziecka). M. Montessori była przekonana, że jej podejmowanie uwarunkowane jest sensorycznym i motorycznym przygotowaniem dziecka, które określała alfabetem, bez którego dziecko nie jest w stanie wyrażać tego, co stanowi jego osobowość (Montessori 2010: 227). Sens tego, jakie działania powinien podjąć dorosły, by uwolnić ekspresję dziecka, ujęła w słowach: „Trzeba dać dziecku oko, które widzi, rękę, która jest mu posłuszna, duszę, która potrafi kontemplować" (tamże: 227). Stąd proponowała materiał zwany „metalowymi matrycami”, który służył (i do dziś służy w placówkach montessoriańskich) do odrysowywania kształtów geometrycznych w izolacji, a następnie w rozmaitych kombinacjach. Wykonanie pięknych, dekoracyjnych kompozycji kolorowymi kredkami wymagało wielokrotnie czynności związanych z obrotem figury, jej przesunięciem, ale także respektowaniem zasad symetrii.

Nieocenioną inspirację do rysowania, malowania, a zwłaszcza do postrzegania figur geometrycznych, stanowiło w wyobrażeniach M. Montessori, badanie budowy roślin i ich elementów. Na podstawie własnych obserwacji pracy dzieci, wnioskowała, że w przedmiotach z najbliższego otoczenia, takich jak, okna, ramki, ramy okien i obrazów, czy blat stołu, a więc w tych, w których przeważa jeden kształt powierzchni, nietrudno dziecku dostrzec podstawowe płaskie figury geometryczne (poznawane podczas pracy z ,szafką geometryczną"). Jednakże rozpoznawanie przez dzieci brył geometrycznych, zwłaszcza w skomplikowanych w budowie roślinach, ma miejsce - jej zdaniem - niezwykle rzadko (Montessori 2014: 147). Wymaga ono bowiem niezwykłej uwagi i kontemplacji. Badaczka dostrzegając skupienie dziecka nad „studiowaniem” części kwiatu uznała, że należy w klasie gromadzić przyrządy niezbędne do rzetelnej obserwacji, takie jak: pęsety, szpilki, lupy, a także mikroskop. Jej wychowankowie poczynione spostrzeżenia rejestrowali samodzielnie na kartkach papieru, za pomocą ołówków, akwareli, kredek, a także z wykorzystaniem cyrkla (tamże: 228).

Przedstawiony zarys wybranych fragmentów założeń pedagogicznych F.W. Fröebla i M. Montessori miał za zadanie zwrócić uwagę na nieprzemijającą wartość określonych 
poglądów i idei pedagogów, którzy tworzyli koncepcje kształcenia i wychowania w odmiennych od dzisiejszych warunkach cywilizacyjnych, politycznych, społecznych, kulturowych. Zwłaszcza starano się ukazać, jak wyraźnie akcentowali zagadnienia dotyczące kształcenia dzieci w zakresie treści geometrycznych i jakie znaczenie w tym względzie ma bezpośrednie doświadczanie otoczenia.

\section{Gromadzenie doświadczeń geometrycznych inspirowane klockami Esy floresy - badania w działaniu}

Materiały dydaktyczne i poglądy pedagogiczne F W. Fröebla oraz M. Montessori zainspirowały do zaprojektowania ${ }^{1}$ klocków i towarzyszących im materiałów pomocniczych nazwanych Esy floresy i podjęcia uczestniczących badań w działaniu, by tym samym zainicjować proces zmiany w zakresie osobistym i profesjonalnym oraz w zakresie praktyki edukacyjnej.

Badania w działaniu charakteryzują się integracją myśli pedagogicznej teoretyków i nauczycieli praktyków w celu zmiany bądź rozwiązania problemu. Można je określić jako tak zwane badania rozwojowe, użyteczne w pedagogice zorientowanej praktycznie. Są to badania, które polegają na opracowaniu programu zmian i wywołaniu tych zmian w obrębie zjawisk i procesów pedagogicznych. Zabiegi te mają sprzyjać osiąganiu nowych kompetencji podmiotów oddziaływań dydaktyczno - wychowawczych oraz doskonalić proces ich nauczania i uczenia się. W realizację zmian w toku badań zaangażowani mogą być zarówno badacze profesjonalni, jak i nauczyciele czy rodzice. Cykl badań rozwojowych obejmuje następujące etapy: ,sformułowanie programu zmian, wypracowanie programu zmian, wdrażanie programu do praktyki, ewaluację programu (bieżącą i końcową), określenie użyteczności praktycznej i zakresu stosowalności programu, sformułowanie uogólnień, upowszechnienie programu" (Palka 2006: 56). Jak podaje Krystyna Chałas (2015: 122), badania w działaniu znoszą w pewnym stopniu świadomie i celowo dystans między badaczem a praktykiem, na korzyść ich współpracy zarówno na gruncie nauki, jak i praktyki edukacyjnej. Są one powiązane z praktyką społeczną lub pedagogiczną, ingerują w praktykę i same muszą się otworzyć na sygnały płynące z praktyki. Ich idea jest integralnie związana z refleksyjnością myślenia, działania i badania. Przedmiotem analizy w badaniach w działaniu mogą być zmiany w dyspozycjach osobowościowych, w relacjach społecznych albo w treściach i organizacji pracy (Czerepaniak-Walczak 2010: 320).

\footnotetext{
1 Wzory klocków, matryc i schematów pomocniczych zostały zaprojektowane przez B. Bilewicz-Kuźnię i Jolantę Bajun (studentkę pedagogiki w WSP im. J. Korczaka w Lublinie); matryce graficzne okien, drzwi, bram służących do układania na nich klocków, schematy dydaktyczne do układów pasowych, krzyżowych i rozet oraz matryce do wycięcia klocków wykonał architekt Marek Bajun; zdjęcia natury, pomoce do nauki nazw elementów architektury, opartych na motywach roślinnych opracowała M. Centner-Guz. Materiały i sposoby ich wykorzystania były prezentowane przez autorki artykułu na warsztatach pt. Horror vacui na XIII Kongresie M. Montessori w Rzymie w dn. 26-28.10.2012 oraz zajęciach dydaktycznych w WSP im. J. Korczaka i UMCS w Lublinie.
} 
Projektując uczestniczące badania w działaniu, kierowałyśmy się kilkoma motywami. Pierwszym była potrzeba organizowania sytuacji edukacyjnych angażujących dzieci, nauczycieli i badaczy. Zależało nam, by w oparciu o model kooperacyjny zweryfikować w praktyce opracowane propozycje metodyczne zajęć artystyczno-matematycznych w przedszkolu oraz sprawdzić przydatność zaprojektowanych materiałów w rzeczywistym działaniu. Innym ważnym celem badań była chęć twórczego zaktywizowania samych siebie, dzieci i nauczycieli.

Zaprojektowanie klocków i związanych z nimi działań wynikało z kilku potrzeb: potrzeby zwrócenia większej uwagi praktyków na czynnościowe nauczanie matematyki, potrzeby organizowania twórczych działań dydaktycznych o charakterze zabawy, zaakcentowania wykorzystania przestrzeni społecznej w edukacji estetycznej i matematycznej oraz potrzeby budzenia aktywności intelektualnej dzieci. W badaniach kierowałyśmy się przekonaniem o prymacie czynnościowych metod nauczania - uczenia się, oferujących możliwość manipulowania, działania ruchowego, badania, projektowania, zabawy, praktycznego rozwiązywania problemów. Nasze zamierzenia związane były z niegodzeniem się na akcentowaną przez niektórych badaczy (Rura, Klichowski 2011: 219) edukację matematyczną o charakterze werbalno-nakazowym, często opartą na pokazie, wyjaśnianiu i powtarzaniu określonych algorytmów czynności. Stąd główną metodą realizacji naszych zajęć była metoda czynnościowa w opracowaniu Zofii Krygowskiej (1977), która w działaniach edukacyjnych stroną aktywną czyni przede wszystkim dziecko. Istotę strategii czynnościowej w nauczaniu matematyki wyjaśnia Helena Siwek pisząc, iż jest ona metodą ,realizującą podejście konstruktywistyczne, w którym uczeń konstruuje swoją wiedzę w interakcji z materiałami, zadaniami, na drodze bogatych doświadczeń, pod kierunkiem nauczyciela i we współpracy z kolegami” (1998: 11). Nasze działania nawiązywały także do nauczania realistycznego Hansa Freundenthala, zakładającego „wychodzenie w nauczaniu od sytuacji rzeczywistych, stawiając sobie za cel matematyzację pionową, budowanie kolejnych pięter abstrakcji” (tamże: 11). Jednocześnie zależało nam na uwrażliwieniu społeczności przedszkolnej na różne zagadnienia i treści geometryczne, nie ograniczając ich jedynie do poznawania podstawowych kształtów figur, układania rytmów, czy określenia położenia przedmiotów w przestrzeni. Chęć zmiany była poparta konkluzjami badaczy edukacji elementarnej, że jest w niej „,mało treści geometrycznych, a jeśli już są, ograniczają się do rozpoznawania i nazywania figur geometrycznych, a tymczasem dla dziecka w tym wieku geometria jest atrakcyjną dyscypliną matematyki, bo pozwala wyzwolić jego inwencję twórczą" (Rura, Klichowski 2011: 221). Stąd, podejmując badania, uznałyśmy za ważne zwrócenie uwagi praktyków na twórczą edukację geometryczną, zwłaszcza na dostrzeżenie jej sensu rozwojowego w gromadzeniu nowych doświadczeń i przeżyć estetycznych. Istotnym celem stało się rozwijanie postawy twórczej i towarzyszącej jej wrażliwości estetycznej

Pytania, które sformułowałyśmy we wstępnym etapie badań były następujące: Jak będą przebiegać wspólne działania badaczy, nauczyciela i dziećmi z wykorzystaniem nowych materiałów dydaktycznych? Czy w i jakim zakresie proponowana dzieciom aktyw- 
ność z materiałem będzie wyzwalała intuicje geometryczną i kreatywność? Jak uczestnicy badań w działaniu ocenią proponowane im zajęcia i materiały dydaktyczne?

Badania przeprowadzono dwuetapowo. Pierwszy etap miał charakter wstępny, rozpoznawczy i był zrealizowany w okresie poprzedzającym właściwe badania w Publicznym Przedszkolu nr 33 w Lublinie oraz Szkole Podstawowej nr 50 w Lublinie. Na tym etapie zgromadziłyśmy wstępne doświadczenia metodyczne. Badania właściwe zrealizowano od stycznia do kwietnia 2015 i te są przedmiotem opisu. Grupę badawczą stanowiło 25 dzieci w wieku pięciu-sześciu lat, uczęszczających do Publicznego Przedszkola nr 43 w Lublinie. Zajęcia dydaktyczne były prowadzone systematycznie, co najmniej raz w tygodniu w godzinach przedpołudniowych. Wszystkie materiały były dostępne dla dzieci w czasie ich zabaw swobodnych do końca roku szkolnego.

\section{Podstawy teoretyczne badań}

Podstawą teoretyczną zrealizowanych badań stanowiły poglądy pedagogiczne F.W. Fröebla i M. Montessori, wnioski Lwa S. Wygostkiego, Jeana Piageta, Petera Vopěnki i Milana Hejný'ego, Zofii Krygowskiej i Heleny Siwek.

Podjęte przez nas badania zostały oparte na założeniu, że świat geometryczny nie jest możliwy do bezpośredniego postrzegania, lecz jest ukryty w świecie realnym. Jak podkreślają F.W. Fröebel (1826) i M. Montessori (1976, 2014), a także współcześni badacze (zob. Filipiak 2012), dziecko nie zawsze zwróci uwagę na ważne elementy świata, nie zawsze są też one w zasięgu jego ręki, dlatego też dorosły pomaga je odkrywać. Jego rolę akcentował w swoich pismach L.S. Wygotski, który twierdził, że ,dziecko wchodzi w stosunki z sytuacją nie bezpośrednio, ale za pośrednictwem drugiej osoby" (Wygotski 1978: 45). Nauczyciel, rodzic czy kompetentny rówieśnik poprzez bycie z dzieckiem w interakcji o charakterze intelektualnym, pomaga mu osiągnąć więcej, niż gdyby działało ono samo. Dzięki takiej stymulacji dziecko uruchamia aktywność własną i przez to buduje indywidualny obraz świata. $Z$ tego punktu widzenia, dorosły jest również odpowiedzialny za pomoc dziecku w dostrzeganiu piękna przyrody, architektury, odkrywaniu kształtów i relacji przestrzennych oraz stwarzaniu mu warunków do zabawy, w której „przećwiczy” nowe umiejętności.

Punktem wyjścia w zorganizowanych sytuacjach edukacyjnych stała się swobodna zabawa dzieci z nowym materiałem. Kolejnym krokiem była wnikliwa obserwacja przyrody $\mathrm{i}$ badanie detali architektury w terenie i na fotografiach, poszukiwanie znanych kształtów i regularności. Następnie dzieci podejmowały działania polegające na tworzeniu wzorów i szlaczków układanych z klocków, ozdabiały modele elementów architektonicznych (okna, bramy, tarasy) oraz odrysowywały ich kształty, kolorowały je, stemplowały i tworzyły własne wzory. Zaprojektowanie tego typu działań wynikało z teorii kształcenia geometrycznego.

Zdaniem P. Vopěnki i M. Hejný’ego, kształty i relacje przestrzenne wyłaniają się, choć nie bezpośrednio, ze świata realnego, a pierwsze i podstawowe poznawanie ma charakter zmysłowy (za: Swoboda 2006: 79). Na pierwszym etapie rozumienia prawidłowości geo- 
metrycznych, zwanym przedpojęciowym, kształty są atrybutami realnych obiektów i ujmowane są jednym aktem percepcji. W umyśle dziecka nie ma geometrycznych obiektów, a jedynie obiekty ze świata realnego, dlatego dziecko na nich skupia uwagę i wyodrębnia je z całej reszty. Takie widzenie przedmiotów czy zjawisk i wyróżnianie ich spośród pozostałych, określa się zjawiskiem (z czes. jev - zjawisko) (Swoboda 2009: 47). Przy czym, jak mawiają niektórzy badacze, geometryczne widzenie nie jest widzeniem przez zmysły. Spoglądanie na świat geometrii jest możliwe „dzięki jakiemuś szóstemu zmysłowi (...)” (Vopenka 1989: 17) i pomocy dorosłego. „Widzieć «to» znaczy skupić na tym uwagę, wyróżnić «to» z całej reszty (...)" (tamże: 17).

Dostrzeżenie czegoś przez dziecko to próby pierwszego zrozumienia. Dziecko może spostrzec interesujący kształt lub położenie przedmiotów względem siebie, podejmując przy tym aktywność intelektualną, zwaną przez P. Vopěnkę i M. Hejný'ego intuicja geometryczna (Vopĕnka 1989, Hejný 1993) W toku takiego poznawania pojawiają się różne formy aktywności, np. manipulowanie, obserwowanie, eksperymentowanie, konstruowanie. Służą one doskonaleniu funkcji spostrzeżeniowych, stanowią okazję do aktywizowania wyobraźni przestrzennej i myślenia matematycznego.

František Kuřina (1995) sugeruje, że aktywność małych dzieci związana z treściami geometrycznymi powinna być zogniskowana wokół dwóch grup czynności. Pierwsza ma być związana z zajęciami konstrukcyjnymi z wykorzystaniem obiektów umożliwiających aranżowanie ich w rozmaity sposób, a także z tworzeniem wzorów czy szlaczków. Druga powinna obejmować rysowanie i malowanie. W zaprojektowanych zajęciach respektowałyśmy sugestie F. Kuřina, a także starałyśmy się tak organizować sytuacje problemowe, by umożliwiały one dokonywanie przez dzieci trzech rodzajów operacji: konkretnych, wyobrażonych i pomyślanych (Siwek 1998: 40). Na przykład czynności konkretne dotyczyły wyróżniania w zestawie klocków znanych kształtów. Czynności wyobrażeniowe obejmowały tworzenie skojarzeń kształtów klocków ze znanymi przedmiotami, nadawanie im nazw, tworzenie grup kształtów podobnych i nazywanie ich, odrysowywanie płytek, rozpoznawanie ich kształtów na schematach pomocniczych, obliczanie z ilu elementów składają się konstrukcje i wzory, itp.

Obecnie autorzy programu realistycznej geometrii rozwijanej w Instytucie Freudenthalla (Utrecht, Holandia), chętnie powołują się na tradycje wypracowane jeszcze przez J.H. Pestalozziego, F.W. Fröebla oraz M. Montessori, których metodyka traktuje zajęcia geometryczne jako niezwykle istotne. Dodatkowo wychodzą także z założenia, że treści geometryczne związane z symetrią, czy też przesunięciem i obrotem figur, nie są zarezerwowane jedynie dla uczniów szkół średnich (Swoboda 2006: 47).

\section{Material dydaktyczny}

Wykorzystany w badaniach zestaw klocków składa się z 312 elementów wyciętych z białej płyty pleksi. W komplecie znajduje się 13 zróżnicowanych kształtów, które zostały zaczerpnięte z motywów przyrodniczych i architektonicznych. W zestawie są klocki w kształcie 
figur geometrycznych, takich jak: koło, trójkąt, kwadrat, prostokąt, trapez, połowa koła, elipsa oraz klocki o motywach roślinnych i zdobniczych: listek, kwiat, litera C, S, łuk, rama kąta. Każdy rodzaj klocka występuje w dwóch wielkościach: jako duży (12 cm) i mały (6 $\mathrm{cm}$ ) w liczbie 12 sztuk. W skład kompletu wchodzą również matryce okien, drzwi, balkonów, bram, wydrukowane na papierze dużego formatu, z podkładem sieci kwadratowej o kwadratach 6x6 centymetrów dla skutecznego „uchwycenia proporcji” pomocnych przy projektowaniu zdobień, szablony pomocnicze do odwzorowywania kształtów i liczne fotografie (owoców i warzyw w przekroju, motywów zdobniczych w architekturze).

\section{Twórcze działania poznawcze}

Pierwsze spotkanie z dziećmi miało wzbudzić ich zainteresowanie nowym materiałem i wywołać konflikt poznawczy. Wniosłyśmy pudełko z klockami, potrząsając nim energicznie i zapytałyśmy: Jak myślicie, co może się tam znajdować?. Dzieci zgadywały, potem badały klocki z zamkniętymi oczami, snuły przypuszczenia. Po otwarciu brały klocki do rąk i mówiły do czego są podobne, co im przypominają. Na tych zajęciach starałyśmy się stworzyć pozytywny klimat, pozostawiając dzieciom swobodę w doświadczaniu materiału dydaktycznego.

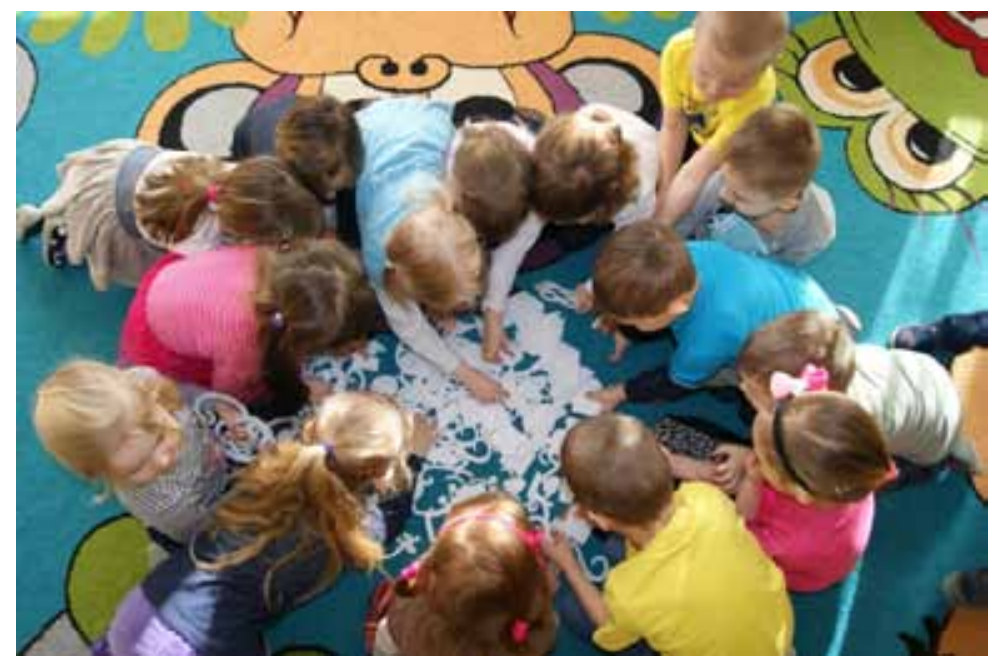

Fot. 1. Pierwszy kontakt dzieci z klockami

Źródło: własna dokumentacja fotograficzna

Dzieci z wielkim zainteresowaniem zbliżyły się do klocków, wybierały przeważnie jeden element, oglądały go i porównywały z klockami kolegów i koleżanek. Zwracały się do siebie, komentując kształt i wielkość posiadanego klocka (np. o..., taki, yes, o mamy taki sam, super, mam jeszcze jedno, kółeczko, kwiatek, jajka, malutki). Wiele z nich z wyraźną ekscyta- 
cją pokazywało wybrane elementy nauczycielowi (proszę Pani taki) i innym dzieciom (mam taki, zobacz). Kilkoro przedszkolaków, szczególnie tych, które miały klocki o artystycznych kształtach (listek, kształt S, C), nakładało elementy na głowę lub uszy, dekorując siebie i pokazując innym odkryte przeznaczenie klocków (użyły ich jako kolczyki, naszyjnik, diadem). Po wstępnej eksploracji klocków zaproponowano dzieciom swobodną zabawę.

Rozpoczęly one gromadzenie tych samych kształtów, wybierając po jednym lub po kilka ich rodzajów. Podchodziły do wyłożonych na środku dywanu klocków, wyszukiwały takie, które były im potrzebne i odchodziły na wolne miejsce na dywanie. Tam próbowały łączyć klocki ze sobą, układając je obok siebie, jeden na drugim lub tworząc łańcuch poprzez zawieszanie na sobie elementów. Przedszkolaki zapraszały kolegów i koleżanki do wspólnych działań, mówiąc np. ustawimy razem, daj, proszę tu jest reszta, mogę to? Zaobserwowano, że w toku tych działań pojawiły się rytmy o charakterze pasowym, z mniej lub bardziej widoczną regularnością. Układając klocki dzieci łączyły elementy tego samego rodzaju tworząc płoty, budowały ornamenty dekoracyjne z zachowaniem symetrii, układały kształty zwierząt, pojazdów.
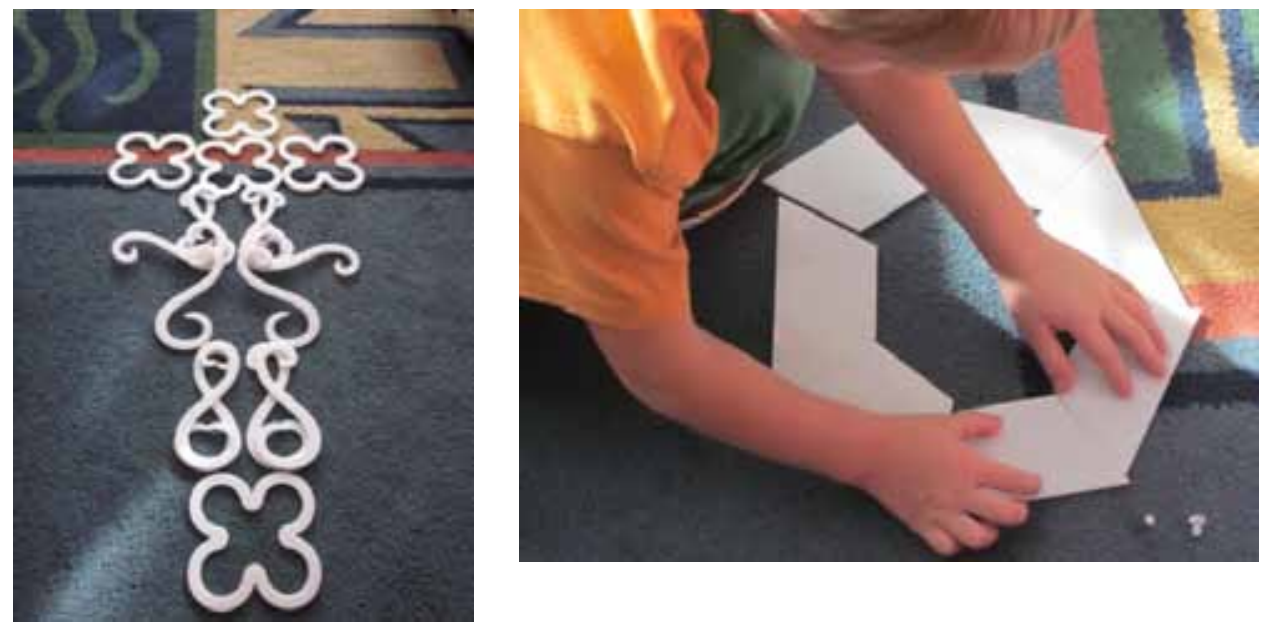

Fot. 2, 3. Pierwsze kompozycje z kloców

Źródło: własna dokumentacja fotograficzna

W trakcie swobodnego konstruowania widoczne było zróżnicowanie płciowe, co przejawiało się w treści kompozycji. Dziewczynki układały przeważnie kwiatki i nieokreślone symetryczne dekory. Chłopcy konstruowali samochody, domy, statki, roboty. W trakcie działania dzieci używały języka matematycznego, np. stosowały określenia mały, malutki, taki sam, inny; przeliczały elementy, układały jeden na drugim, nazywały je (jajka, szlacz$k i$, kwiatek, C), rzucały nimi do celu, a także szukały u innych potrzebnych kształtów, otaczały stworzone konstrukcje poprzez układanie ogrodzenia, tym samym wyznaczając sobie przestrzeń działania. 

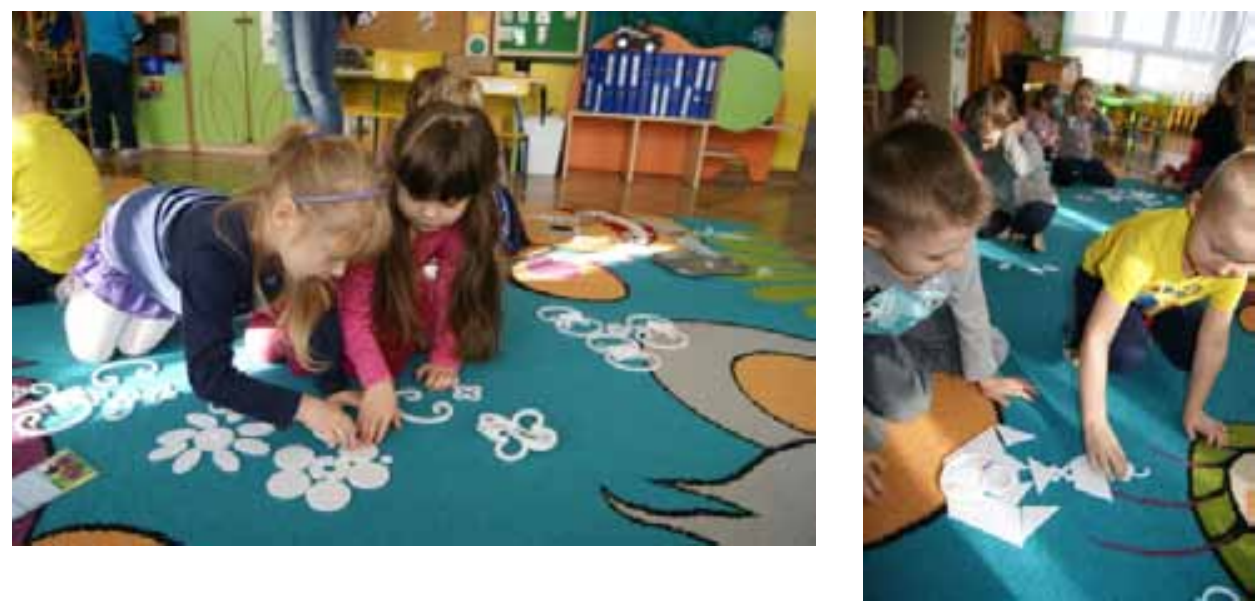

Fot. 4, 5. Spontaniczne działania twórcze w diadach i małych grupach

Źródło: własna dokumentacja fotograficzna

Dzieci łączyły się w zespoły tworząc wspólne dzieła. Zauważyła to również nauczycielka: Dzieci podczas zabaw swobodnych przy stolikach lub na dywanie uktadaty samodzielnie cykle ornamentów, które stopniowo łączyly w jedna kompozycję z wzorami innych dzieci, co sprzyjało ogromnej integracji. Niewiele osób działalo samotnie (N1).

W trakcie zajęć dzieci były bardzo podekscytowane, wyraźnie zaangażowane w działanie. Po zajęciach przedszkolaki mówiły, że klocki są fajne, podobało mi się budowanie, uktadanie statków, samolotów, ozdabianie, itp.

\section{Odwolanie się do natury}

Kolejne zajęcia z dziećmi miały nieco odmienny charakter. Nasze działania nastawione były na budowanie w umysłach dzieci pojęcia symetrii. W tym celu wykorzystałyśmy naturalne okazy przyrodnicze. Dzieci uważnie oglądały przekrojone na pół kiwi, pomarańcze, pomidory, brokuły, cebulę, badały je za pomocą lusterka. Zapytane, co dostrzegają, same odkrywały, że części warzyw i owoców pokrojone wzdłuż, w poprzek i ukośnie są takie same albo różne. Sytuacja ta umożliwiła rozmowę o symetrii i asymetrii oraz inspirowała do poszukiwania jej w innych eksponatach. Na kolejnym spotkaniu udostępniłyśmy dzieciom fotografie owoców i warzyw w przekroju (po kilka egzemplarzy jednakowych obrazów). Dzieci próbowały domyślić się zadania, niektóre z nich trafnie odczytały nasze intencje i rozpoczęly tworzenie wzorów.

Początkowo dzieci układały zdjęcia w dowolny sposób, następnie udostępniłyśmy im szablon ilustrujący układ pasowy, krzyżowy i rozetowy elementów. Dzieci nadawały tytuły swoim kompozycjom (np. obraz pestkowy - o pomarańczach; obraz rombowy z cebuli, drzewo brokulowe, robot kapuściany, obraz pomidorowy, obraz ,kiwiowy”, kro- 
kodyl z kiwi). Dzieci przyporządkowywały uprzednio przygotowane podpisy (kompozycja brokułowa, kompozycja pomidorowa, itp.) do stworzonych wzorów, a te, które nie umiały czytać, wykorzystywały kontrolę błędu (wizualną podpowiedź na rewersie podpisu). Zapisano też nazwy stworzone przez dzieci. Zajęcia zakończono rysowaniem wzorów z owoców i warzyw ułożonych ze zdjęć. Aktywność ta została przez dzieci określona jako trudna, niektóre z nich twierdziły: trudne jest to rysowanie.

Działania twórcze bardzo zaciekawiły dzieci, niektóre z nich powracały do zaproponowanych aktywności w kolejnych dniach. Nauczycielka relacjonowała, że już dzień później, od rana, kilka dziewczynek zwróciło się do niej z prośbą o udostępnienie zdjęć owoców i warzyw, gdyż chciały zająć się ich układaniem.

\section{Wyprawa w teren w poszukiwaniu motywów zdobniczych}

Kolejna aktywność dydaktyczna miała charakter wyprawy terenowej, charakterystycznej dla metody projektu. Jej celem było odnajdywanie motywów zdobniczych zaczerpniętych z natury. Wyjście poprzedzono oglądaniem zdjęć i prezentacji multimedialnej. Przygotowałyśmy multimedialny pokaz ilustrujący detale architektoniczne starego miasta Lublina, Krakowa, Gdańska i Torunia. Zwracałyśmy uwagę na powtarzające się motywy zdobnicze widoczne na drzwiach, gzymsach, okiennicach, murach, bramach, tabliczkach. Następnie dzieci oglądały zdjęcia okazów przyrodniczych (ślimaka, kwiatu lotosu, akantu, róży, winogrona), szukały tych samych motywów na fotografiach, a po wprowadzeniu ich nazw, podpisywały ilustracje obiektów (woluta, rozeta).

Wyprawa terenowa była efektem rozmowy dzieci z nauczycielem, a same dzieci nadały jej nazwę $W$ poszukiwaniu wzorków. Ich zadaniem było zapamiętanie wybranego motywu naturalnego (np. ślimaka, róży, liścia, czy innych) i odnalezienie go w trakcie spaceru. Jedna z grup udała się na Stare Miasto, druga na spacer po okolicy. Dzieci poszukiwały znanych motywów przyrodniczych i nieznanych zdobień, nazywały je, rozpoznawały kształty figur geometrycznych, komentowały spostrzeżenia, posługując się nazwami gatunków roślin i zwierząt (ślimak, róża, winogrono), motywów zdobniczych (woluta, akant, rozeta) oraz figur geometrycznych (koło, owal, prostokat).

Po powrocie nastąpiła wymiana wrażeń i spostrzeżeń. Relacjonowane działania zostały ujęte przez nauczyciela w następujący sposób: Prezentacje multimedialne, pokazy zdjęć zabytkowych budynków były wprowadzeniem, ale wyprawy terenowe byty dla dzieci niesamowita okazją do zdobywania doświadczeń, inspiracji, wyszukiwania wzorów wokót siebie, które następnie uktadane byly w czasie zajęć. Dawno dzieci nie byly tak aktywne i zainteresowane (N1).

Po wyprawie terenowej kilkakrotnie powracano do materiału i dodatkowo wzbogacono go graficznymi schematami, kartami pomocniczymi do układania ornamentów pasowych, kołowych i krzyżowych. Każda karta zawierała zdjęcie elementu naturalnego np. kwiatu oraz schematy jego ułożenia z klocków. Dla niektórych dzieci stało się to ważnym bodźcem rozwojowym. Wiele z nich chętnie korzystało z kart, skutkiem czego 
układanych zdobień było więcej, były one bardziej zróżnicowane i bogatsze jakościowo. Po omówieniu zajęć dostrzegłyśmy, że pod wpływem obserwacji natury i architektury oraz kart - wzorów pomocniczych, znacznie wzrosła aktywność manipulacyjna z wykorzystaniem klocków. Dzieci tworzyły bardziej oryginalne wytwory i chętnie się o nich wypowiadały.

$\mathrm{Na}$ kolejnych zajęciach zaproponowałyśmy dzieciom dodatkowy materiał - wydrukowane na dużych płóciennych płaszczyznach schematy elementów architektonicznych okien, drzwi, bram. Zadaniem dzieci było podzielenie się na 4 grupy. Każda grupa dostała jeden duży schemat: drzwi, okno gotyckie, okno z balkonem lub bramę. Dzieci uważnie obejrzały swoją matrycę i wybrały do ozdabiania jej klocki w 5 różnych kształtach. Zapytane, co im przypominają dane kształty i co można z nich zrobić, odpowiadały, że kształty przypominaja litery, figury geometryczne: kótka, owale, kwadraty, zwierzątka: ślimaki, dżḋownice, robaki, motyla, patyczki, listki, kwiatki, kropki, daszki, domki, że można z nich układać, bawić się, robić obrazki, ozdabiać, nosić. Następnie postawiono dzieciom zadanie udekorowania matryc. Dzieci zgromadzone wokół schematu, metodą prób i błędów, ustaleń i negocjacji ozdabiały swoje okno, bramę lub drzwi. Po zakończeniu dekorowania opowiadały, co to za okno, drzwi czy brama, z jakiego jest budynku, kto tam mieszka lub co tam się znajduje. Prowadząca wykonała zdjęcie dekoracji i nastąpiła zamiana grup. Materiał do dekorowania, czyli pięć rodzajów klocków został ten sam, ale zmieniła się grupa dekoratorów. W taki sposób dzieci, które zdobiły wcześniej np. okno, po przejściu na miejsce pracy kolegów zdobiły to, co poprzednicy, np. drzwi. Po wykonaniu zdobienia dzieci zgłosiły, że można już zrobić zdjęcie i nastąpiła prezentacja pomysłów. Wszystkie dzieci ozdabiały 4 różne elementy architektoniczne. Zdjęcia zostały w późniejszym czasie udostępnione, co stało się okazją do porównań efektów działania.

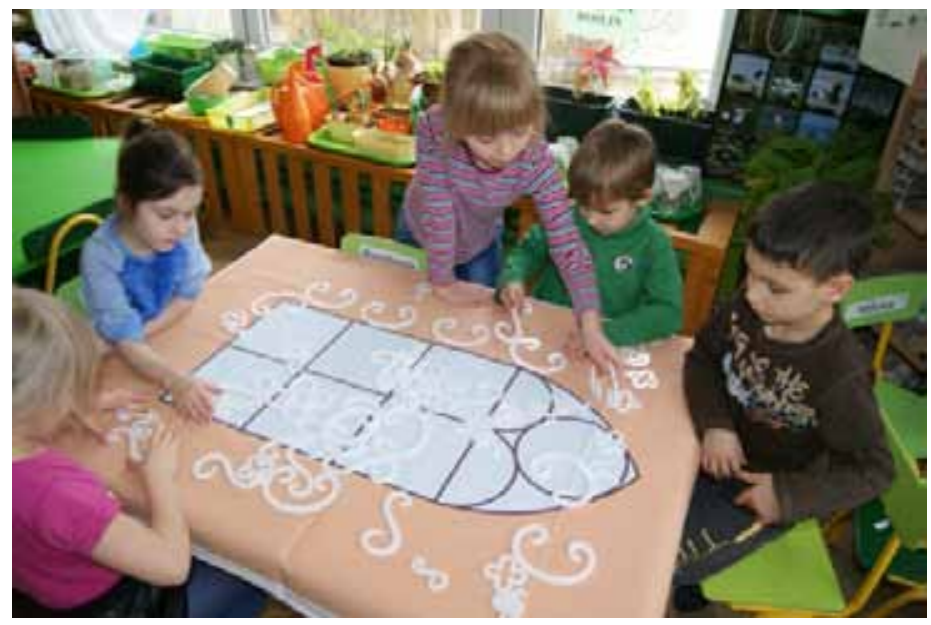

Fot. 6. Dekorowanie w zespołach

Źródło: własna dokumentacja fotograficzna 
Oto fragmenty protokołu z jednych zajęć:

\author{
N.: Co to jest? Gdzie sa takie okna? \\ Dz.1.: To światynia. \\ Dz.2: $W$ kościele. \\ N.: Kto mieszka w budynkach z takimi oknami? \\ Dz.1: Ksiadz, bo ma ładne domki.
}

Dz.2: Królowa Jadwiga, ona jest patronka szkoły mojego brata, w szkole jest taki obraz, na którym Jadwiga trzyma pieniążek, ona mogła mieć takie okna.

Dz.3: Pan Bóg; Święty Pan.

Dz.4: Dodatkowo okna się ozdabia, żeby byly tadniejsze; można firankami albo ozdóbkami. To może być taki obrazek na ścianie, który widać przez to okno.

Po zamianie ról druga grupa dzieci skomentowała swoją pracę w następujący sposób:

Dz.1: To sa ładne okna, a przez nie patrzy księżniczka w sukni.

Dz.2: Tu mieszka prezydent albo nawet premier.

Dz.3: To sa okna w Warszawie.

Dz.4: Mieszka za oknem jakaś pani dama i pan.

Po zamianie ról i ponownym projektowaniu na szablonie rozmowa z autorami kompozycji przebiegła następująco:

N.: Gdzie sa takie okna?

Dz.1: W zamku

Dz.2: W rakiecie (ksztalt okna podobny do rakiety)

Dz.3: W wielkim domu, gdzie jest porzadek i pokoje, i sypialnie.

Dz.4: Wieża, wiatrak.

Dz.5: W muzeum, w zamku

Dz.6: W teatrze, tam sq okna zdobione i maja inny ksztatt niż w przedszkolu.

Dz.7: Mieszka tam księżniczka

Kolejna grupa wyjaśniała:

Dz.1: Bardzo fajne klocki, można sobie nimi ozdobić okno.

N.: Gdzie sa takie okna?

Dz.1: W wieży, $w$ zamku, $w$ dużym domu albo nawet $w$ domu kultury.

Dz.1: Mieszkają tu król i królowa; księżniczki i książęta i mały książę; straże zamku patrza przez te okna.

Dz.3: To, co ułożyliśmy to moga być takie firanki.

Z zapisu wynika, że zaproponowane zajęcia sprzyjały także ujawnieniu się postaw twórczych. Rozmowa poprowadzona z dziećmi na temat prac pomogła dowiedzieć się więcej o dziecięcych wyobrażeniach, a wzajemne słuchanie i porównywanie wypowiedzi sprzyjało rozwojowi giętkości i oryginalności myślenia i wyobraźni. 


\section{Opinie na temat materiałów dydaktycznych i zajęć}

Interesowało nas, czy klocki podobają się dzieciom i czy dostrzegają one ich odmienność od klocków tradycyjnych. Na pytanie: Czym różnia się te klocki od innych? dzieci powiedziały:

\section{Dz.1: Sa tu różne nowe wzorki.}

Dz.2: Ksztatty te podobne sa do kwiatka, serduszka, koniczynki, truskawki, litery S i haczy$k a$, wasy.

Dz.3: Można na walentynki odrysować i komuś dać - babci albo cioci albo nawet wujkowi. Dz.4: Klocki różniq się od innych ,ksztaltnościq", sa takie kwadrat i prostokąt, a te to nie wiem, jak się nazywaja; tu sa różne ksztalty: zawijaski, iksy, kotyski, jabluszka w ksztatcie serduszka; można ukladać z nich wózek, kołyskę, karetę zamki z ozdobami na ścianach $i$ w oknach; domy duze i rakietę, zabawki. Fajne jest to uktadanie, bo daje dużo pomystów; układamy co innego niż zwykte budowy.

Z fragmentu wypowiedzi wynika, że dzieci dostrzegły estetyczne i twórcze możliwości i walory klocków. Były one według nich materiałem do układania innych konstrukcji niż tylko budowle. Można wysnuć wniosek, że tego rodzaju klocki prowokują do tworzenia niecodziennych form dekoracyjnych. Zauważono, że w kontakcie z klockami dzieci sprawnie abstrahowały znane kształty figur geometrycznych, porównywały i porządkowały klocki w różny sposób, zmieniały ich położenie wykorzystując translacje i rotacje, przeliczały, posługując się przy tym językiem matematyki. Potwierdziły to także nauczycielki:

Materiał dydaktyczny - ornamenty już podczas pierwszego kontaktu wzbudził w dzieciach ogromne zainteresowanie. Wzory rozsypane na środku dywanu prowokowały dzieci do porządkowania, segregowania, nazywania kształtów oraz tworzenia swobodnych kompozycji płaskich i przestrzennych. Materiał prowokuje dzieci do podejmowania działań wspólnych w zespole i w parach; porównywania prac stworzonych samodzielnie, są tu różne obrazy z tych samych elementów, niepowtarzalność, indywidualizm. Klocki pozwalają na układanie wzorów na płaszczyźnie i przestrzennych, dokonywanie przekształceń, dowolne dokładanie i zabieranie elementów w celu stworzenia nowej jakości; sprzyjają rozwojowi zainteresowań architekturą, wyzwalają poczucie piękna i estetyki (N1).

Obie pracujące $\mathrm{w}$ grupie nauczycielki podkreśliły znaczenie materiału dydaktycznego w wyzwalaniu twórczej aktywności poznawczej i w budzeniu zaciekawienia dzieci architekturą i sztuką. Dostrzegły także, iż praca dzieci z klockami zachęca do współdziałania i dążenia do realizacji wspólnego celu, jak również - w odniesieniu do dzieci, które preferują samodzielne działanie - umożliwia odnoszenie indywidualnych sukcesów. W ocenie nauczycielek, powstające w efekcie działania dzieci kompozycje, przyczyniają się do ich uwrażliwiania na piękno zdobień architektonicznych. Nauczycielki dostrzegły przenikanie się estetyki i matematyki w twórczym działaniu dziecka z wykorzystaniem klocków. Wyraziły to w następujących słowach: 
Zabawy w grupach - ozdabianie ornamentami szablonów bram, okien, drzwi, framug, kolumn budowały dziecięce poczucie piękna i estetyki. Tworzone ornamenty były zazwyczaj rytmiczne, symetryczne. Zabawy takie rozwijają umiejętność współpracy, ale także koordynację wzrokowo-ruchową, orientację w przestrzeni (N1). Niespotykane dotąd kształty klocków inspirują dzieci do podejmowania zabaw nowego typu: projektowanie wzorów symetrycznych z wykorzystaniem elementów o nieregularnej formie (N2)

Nauczycielki zauważyły, że dzieci koncentrowały się na działaniu dłużej niż zwykle. Według opinii nauczycielek materiał był nowy i zachęcał do aktywności twórczej.

Materiał ten stanowi alternatywę dla zabawek komercyjnych, jednolity kolor i gładka faktura nie rozprasza - pozwala skupić się na kształcie klocka - nie ma niepotrzebnych bodźców dodatkowych, chaosu (N2).

Nauczycielki podkreśliły ponadto, że działania z materiałem wyzwalają aktywność werbalną:

W czasie spotkań dzieci miały okazję do rozwijania swojego słownika, chętnie opowiadały o tworzonych przez siebie kompozycjach, układały opowieści, wymyślały nazwy. Podczas kolejnych zajęć widać było rozwój wyobraźni, wzory stawały się coraz bardziej rozbudowane. Doskonałą zabawą o ogromnych walorach poznawczych było stemplowanie przygotowanymi materiałami na szarych arkuszach papieru oraz odrysowywanie, a następnie kolorowanie wzorów (N1).

Nauczycielki zwróciły także uwagę na szczególny stosunek dzieci dla materiału, który przejawiał się w ich trosce o porządkowanie klocków:

Klocków - ornamentów było bardzo dużo. Zastanawiałam się, czy dzieci nie znudzą się szybko zabawą, czy nie pogubią, zniszczą nowych pomocy. Okazało się, że tworzenie było dla nich tak inspirujące i wciągające, że klocków mogłoby być jeszcze więcej, a żaden z nich nie został zniszczony czy rzucony w kąt. Po zakończonych pracach dzieci składały materiały na miejsce, segregowały, dbały, aby nic się nie zgubiło. Kontakt z klockami zachęcał dzieci do obserwowania i odtwarzania wzorów zauważonych w otaczającej architekturze, a także do tworzenia własnych (N1).

Obserwacja dzieci pracujących z materiałem dydaktycznym Esy floresy pozwoliła zgromadzić nauczycielom wiele trafnych własnych badawczych spostrzeżeń:

Poprzez działania swobodne rozwija się pomysłowość, kreatywność, twórczość dziecka. Dzieci bazuja na wyobraźni, wyzwala się poczucie sprawstwa. Poprzez pracę ze wzorem dzieci ćwicza spostrzegawczość, dostrzegają ksztatty, zależności i symetrię, skupiaja uwagę; porównują ksztalty, rozwijaja inteligencję wizualno-przestrzenna..., to przygotowuje do matematyki szkolnej. Brak jest na naszym rynku takich klocków, które zachęcaja do zabawy i odkrywania geometryczności świata. To bardzo wartościowa pomoc dydaktyczna (N2). 


\section{Zakończenie i wnioski}

Przedstawione rozważania i poczynione w trakcie badań spostrzeżenia pozwalają na sformułowania wniosków i refleksji końcowych.

1. Podjęte badania w działaniu dostarczyły wielu pozytywnych wrażeń i stały się źródłem różnego rodzaju wiedzy. Duże zainteresowanie dzieci i nauczycielek zajęciami, ich otwartość i pozytywne nastawienie przyczyniły się do poczucia satysfakcji u autorek i współuczestników badań. Współpraca zainspirowała pozytywnie wszystkich do dalszych działań. Dzieci chętnie bawiły się i pracowały z materiałem do końca roku szkolnego. Nauczyciele stali się bardziej samodzielni w projektowaniu zajęć z klockami i zaczęli realizować własne pomysły. Autorki zgromadziły wiele spostrzeżeń metodycznych (np. to, że bodźcem zakłócającym pracę dzieci z materiałem może być miejsce pracy (wielokolorowy dywan), czy np. że propozycje i pomysły dzieci, często zupełnie odmienne od założeń dorosłego, mogą atrakcyjnie i z pożytkiem zmienić tok zajęć.

2. Klocki to przykład środka dydaktycznego skutecznie wspierającego rozwój myślenia przestrzennego i twórczego, zarówno w działaniach swobodnych, jak i kierowanych przez nauczyciela. Zweryfikowano, że są środkiem dydaktycznym umożliwiającym czynienie spostrzeżeń dotyczących kształtu, wielkości, przestrzeni i liczby i rozwijającym wyobraźnię. Sprzyjają ujawnieniu się intuicji geometrycznej, są pomocne w procesie uczenia regularności, rozumienia pojęcia symetrii i asymetrii, dostarczają przeżyć estetycznych. Warto kontynuować tego rodzaju badania i weryfikować walory innych materiałów dydaktycznych, różnych jakościowo klocków, materiałów przyrodniczych czy plastycznych realizując podobne, czy odmienne pomysły metodyczne.

3. Działania edukacyjne z uwzględnieniem zasad konstruktywistycznego nauczania przynoszą satysfakcjonujące zmiany u wszystkich partnerów procesu edukacyjnego. Interakcje z materiałem Esy floresy, pod kierunkiem dorosłego i we współpracy z kolegami i koleżankami w środowisku rzeczowym i kulturowym, sprzyjają budowaniu pozytywnych relacji z innymi oraz konstruowaniu wiedzy fizycznej, logiczno-matematycznej i społecznej. Przyczyniają się do twórczych zmian rzeczywistości edukacyjnej.

\section{Literatura}

Bałachowicz J. (2004), Konstruktywne nauczanie i uczenie się jako podstawa nowoczesnego progresywizmu. W: E. Smak, S. Włoch (red.), Edukacja poprogresywistyczna. Opole, Wydawnictwo Uniwersytetu Opolskiego.

Berg H.K. (2006), Imagination und kreativer Prozess - Bildende Kunst und Musik in der Montessori-Pädagogik. W: H. Ludwig, Ch. Fischer u.a. (Hrsg.), Musik-Kunst-Sprache. Möglichkeiten des persönlichen Ausdrucks in der Montessori-Pädagogik. Berlin, LIT Verlag.

Brzezińska A. (2007), Społeczna psychologia rozwoju. Warszawa, Wydawnictwo Naukowe Scholar. 
Chałas K. (2015), Badania $w$ działaniu czynnikiem wielostronnego kształcenia i doskonalenia nauczycieli. W: S. Guz, M. Centner-Guz, I. Zwierzchowska (red.), W trosce o rozwój i wczesna edukację dziecka. Lublin, Wydawnictwo UMCS.

Cicimirska N. (1928), Moja ochronka. Podręcznik metodyczny. Zbiór pogadanek i pieśni. Lwów, Księgarnia Gubrynowicza.

Cylkowska-Nowak M. (2009), Wczesna, konstruktywistyczna krytyka koncepcji Marii Montessori. W: B. Surma (red.), Dziecko i dorosly w koncepcji pedagogicznej Marii Montessori - teoria i praktyka. Łódź - Kraków, Wydawnictwo Palatum.

Czerepaniak-Walczak M. (2010), Badanie w działaniu. W: Podstawy metodologii badań w pedagogice. W: S. Palka (red.), Gdańsk, Gdańskie Wydawnictwo Psychologiczne.

Davis B. and the Spatial Reasoning Study Group (2015), Spatial reasoning in the early years. Princeples, assertions, and speculations. New York, Routledge.

Filipiak E. (2012), Rozwijanie zdolności uczenia się: z Wygotskim i Brunerem w tle. Gdańsk, Gdańskie Wydawnictwo Psychologiczne.

Fischer R. (2005), Konzeption der Montessori - Pädagogiki. W: R. Fischer (Hrsg.), Sprache Schlüssel zur Welt. Auer Verlag, Donauwörth.

Fröbel F. (1826), Die Menschenerziehung. Wienbrach Keilhau/Leipzig.

Gebhardt-Seele P. (2006), Bildende Kunst in der Montessori-Klasse. W: H. Ludwig, Ch. Fischer u.a. (Hrsg.), Musik-Kunst-Sprache. Möglichkeiten des persönlichen Ausdrucks in der Montessori-Pädagogik. Berlin, LIT Verlag.

Giza T. (2006), Socjopedagogiczne uwarunkowania procesów identyfikowania oraz rozwoju zdolności uczniów w szkole. Kielce, Wydawnictwo Akademii Świętokrzyskiej.

Guz S. (2006), Metoda Montessori w przedszkolu i szkole. Lublin, Wydawnictwo UMCS.

Heýny M. (1993), The Understanding Of Geometrical Concept, Proceedings of the $3^{r d}$. Bratislava International Symposium on Mathematical Education, BISME 3, Bratislava, Comenius University.

Krygowska Z. (1977), Zarys dydaktyki matematyki. Cz. 1. Warszawa, WSiP.

Kubinowski D. (2010), Jakościowe badania pedagogiczne. Filozofia. Metodyka. Ewaluacja. Lublin, Wydawnictwo UMCS.

Kuřina F. (1995), The First Geometrical Experience of a child. Proceedings of International Symposium of Elementary Math Teaching, Prauge, Charles University.

Limont W. (1994), Synektyka a zdolności twórcze. Toruń, Wydawnictwo UMK.

Limont W. (1999), Rozwijanie wyobraźni twórczej. „Wychowanie w Przedszkolu”, nr 6.

Miksza M. (1997), Zrozumieć Montessori. Kraków, Wydawnictwo „Impuls”.

Montessori M. (1976), Schule des Kindes. Freiburg, Herder Verlag.

Montessori M. (2010), Praxishandbuch der Montessori-Methode. Freiburg-Basel-Wien, Herder Verlag.

Montessori M. (2011), Entwicklungsmaterialien in der Schule des Kindes. Renate Götz Verlag, Dörfles.

Montessori M. (2014), Odkrycie dziecka. Łódź, Wydawnictwo „Palatum”.

Nęcka E. (2001), Psychologia twórczości. Gdańsk, Gdańskie Wydawnictwo Psychologiczne.

Palka S. (2006), Metodologia. Badania. Praktyka pedagogiczna. Gdańsk, Gdańskie Wydawnictwo Psychologiczne.

Popek R. (1998), Z badań nad uzdolnieniami plastycznymi młodzieży. Analiza Psychologiczna. Lublin, Wydawnictwo UMCS. 
Popek S. (red.) (1982), Twórczość w procesie rozwoju i wychowania dzieci i młodzieży, Lublin, Wydawnictwo UMCS.

Popek S. (1984), Analiza wartości estetycznych i pozaestetycznych w twórczości plastycznej dzieci W: M. Tyszkowa, B. Żurakowski (red.), Wartości w świecie dziecka i sztuki dla dziecka, Warszawa-Poznań, PWN.

Popek S. (2003), Człowiek jako jednostka twórcza. Lublin, Wydawnictwo UMCS.

Rura G., Klichowski M. (2011), Kompetencje pedagogiczne - założone sposoby ksztattowania i dyskursy popkulturowe W: H. Sowińska (red. nauk.), Dziecko w szkolnej rzeczywistości. Założony a rzeczywisty obraz edukacji elementarnej. Poznań, Wydawnictwo Naukowe UAM.

Siwek H. (1998), Czynnościowe nauczanie matematyki. Warszawa, WSiP.

Surma B. (2008), Pedagogika Montessori - podstawy teoretyczne i twórcze inspiracje w praktyce, Wyd. Palatum, Łódź.

Swoboda E. (2006), Przestrzeń, regularności geometryczne i ksztalty w uczeniu się i nauczaniu dzieci. Rzeszów, Wydawnictwo Uniwersytetu Rzeszowskiego

Swoboda E., Gunčaga J. (2009), Dziecko i matematyka. Rzeszów, Wydawnictwo Uniwersytetu Rzeszowskiego.

Uszyńska-Jarmoc J. (2003), Twórcza aktywność dziecka. Białystok, Trans Humana.

Vopĕnka P. (1989), Rozprawy s Geometrii. Praha, Panorama.

Wąsik W. (1932), Znaczenie Fröebla w historii pedagogiki $i$ w czasach obecnych, „Kwartalnik Pedagogiczny", 3-4.

Wygotski L. (1978), Narzędzie i znak w rozwoju dziecka. Warszawa, PWN.

Żukiewiczowa Z. (1935), Fröebel i Montessori. „Przedszkole” nr 5. 